УДК 616.132-053.2-089.819.5

\title{
Comparison Between Balloon Angioplasty and Surgical treatment for Native Coarctation of the Aorta in Infants
}

\author{
Truba Y., Dzuriy I., Diachenko V., Plyska O., Imanov E., Lazoryshynetz V. \\ National M. M. Amosov Institute of Cardiovascular Surgery National Academy of Medical Sciences \\ of Ukraine (Kyiv)
}

\begin{abstract}
Coarctation of the aorta $(\mathrm{CoA})$ is a discrete stenosis of the proximal thoracic aorta. The common clinical pattern is congestive heart failure in infancy. Treatment methods include balloon angioplasty (BA) and surgical repair in this age group. Percutaneous balloon angioplasty is a less invasive method for the repair of discrete coarctation but remains controversial as a primary treatment strategy for a native coarctation. This study aimed to compare the effectiveness and outcome of balloon angioplasty and surgical repair in infants with coarctation of the aorta younger than one year old.
\end{abstract}

Methods. Between January 2011 and December 2017, 59 patients with native aortic coarctation were treated in National Amosov Institute of Cardiovascular Surgery. This retrospective study evaluated the results of the two methods in patients younger than one year old with the diagnosis of coarctation of the aorta. Group 1 included 18 patients who accepted balloon dilatation for discrete coarctation. Group 2 included 41 patients who underwent surgical resection with end-to-end anastomosis. Patients with complex cardiac anomalies were not included in this study.

Results. Immediate results revealed no significant difference in the effectiveness of the two methods $(p$ value $=0.06)$. While the rate of recurrent coarctation was significantly lower in the surgery group $[1(2,4 \%)$ vs. $13(72,2 \%)$, $\mathrm{p}$ value $=0.0017]$. The mean hospital stay was $6.4 \pm 3.6$ days in the balloon angioplasty group and $21.5 \pm 8.7$ days in the surgery group, which constitutes a significant statistical difference ( $\mathrm{p}$ value $<0.05$ ). Aneurysm formation was not encountered.

Conclusion. Both surgical repair and balloon angioplasty for native coarctation of the aorta in infants were effective and beneficial. These data suggest that balloon angioplasty can be acceptable alternative to surgical treatment but due to the high level of recoarctation this method may be considered in critically ill infants with congestive heart failure as a primary palliative procedure. The limitations of this study were its retrospective, nonrandomized nature, and smaller case numbers.

Key words: aortic coarctation, balloon angioplasty, infants.

Coarctation of the aorta is one of the most common lesion in congenital heart disease that occurs in 4 to $6 \%$ of patients with congenital heart disease, with males being more frequently affected than females and represents a spectrum of aortic narrowing that varies from a discrete entity to tubular hypoplasia [1]. This malformation first described by Johannes Baptista Morgani in 1761 [2]. The first surgical repair of patients with CoA was performed in 1944 by Crafoord and Nylin. In 1983, Lababidi performed the first balloon angioplasty for coarctation of the aorta $[1,2,6]$. Despite many years of experience the optimal management strategy for native aortic coarctation in infants is controversial.

Materials and Methods. Between January 2011 and December 2017, 59 consecutive patients with native aortic coarctation were treated in National Amosov Institute of Cardiovascular Surgery. We divided these patients in two groups according to the kind of treatment. Group 1 consists of 18 patients who underwent balloon angioplasty, Group 2 consists of 41 patients who had a surgical repair. CoA was diagnosed based on a combination of clinical signs and Doppler echocardiographic findings of typical coarctation flow patterns in the isthmus and the descending aorta. If the juxtaductal coarctation was a simple discrete lesion, balloon angioplasty was recommended as a palliative procedure conferring time to small critically ill infants to survive this critical situation, because of immediate relief of the pressure gradient. We began angioplasty by using balloons with a diameter equal to the diameter of the isthmus. If there was inadequate relief of obstruction, a larger balloon with a diameter equal to the descending aorta at the diaphragm level was selected. If the coarctation lesion was associated with long segment stenosis, hypoplastic transverse arch, or tortuous arch, the patients were selected for surgical aortoplasty by end-to-end anastomosis.

Baseline characteristics of the patients, including age, gender, weight, blood pressure. The median age was $97.9 \pm 10.8$ days (range, 1 to 360 days) and the median weight was $4.5 \pm 1.3 \mathrm{~kg}$ (range, 2.0 to $9.5 \mathrm{~kg}$ ). 
Table 1

Patients characteristics

\begin{tabular}{lccc} 
& $\begin{array}{c}\text { Group 1 } \\
\text { Balloon } \\
\text { angioplasty } \\
\text { (n=18) }\end{array}$ & $\begin{array}{c}\text { Group 2 } \\
\text { Surgery } \\
\text { (n=41) }\end{array}$ & p value \\
\hline Female/Male & $6 / 12$ & $10 / 31$ & 0.3 \\
\hline Age (month) & $2.8 \pm 2.1$ & $4.7 \pm 2.3$ & 0.09 \\
\hline Weight (kg) & $4.4 \pm 1.6$ & $6.5 \pm 2.3$ & 0.2 \\
\hline Peak pressure & $59.3 \pm 18.7$ & $57.4 \pm 16.5$ & 0.56 \\
\hline gradient (mmHg) & & & \\
\hline Ejection fraction (\%) & $41.2 \pm 9.7$ & $58.3 \pm 7.4$ & $<0.05$
\end{tabular}

Transcatheter treatment was performed using standard techniques. All procedures were performed under local anesthesia with intravenous ketamine $(1 \mathrm{mg} / \mathrm{kg} / \mathrm{dose})$ for sedation. All patients received prophylactic antibiotic treatment. Intravenous heparin $(100 \mathrm{U} / \mathrm{kg})$ was administered during the intervention. A 4- or 5-Fr right coronary catheter was passed into the descending aorta, and the pressure distal to the CoA was measured. The catheter was then advanced across the CoA and the pressure in the ascending aorta was recorded. Aortograms were obtained from the lateral plane and $15^{\circ}$ left or right of the anterior oblique projection. The diameter of the CoA, isthmus just above the CoA, and the descending aorta to the level of the diaphragm were measured simultaneously. A balloon with a diameter $\leq 1 \mathrm{~mm}$ less than that of the isthmus, or not exceeding the diameter of the descending aorta, was used. After careful positioning, inflations of the balloon catheter were made using contrast with short inflation times ( $<15$ seconds). If there was no significant change in the lesion or the systolic pressure gradient across the CoA was still $>20 \mathrm{mmHg}$, the next size larger balloon was used. Technical success was defined as an immediate reduction in peak systolic pressure gradient across the CoA to $<20 \mathrm{mmHg}$.

In surgery group lateral thoracotomy in the fourth intercostal space was performed in all patients. The descending aorta, as well as the left subclavian and carotid arteries, were exposed and mobilized. The ductus arteriosus was transected. During resection of the stenotic segment of the aorta, care was taken to excise all ductal tissue. Resection of the stenotic segment of the aorta and simple end-to-end anastomosis were performed in all children in the absence of proximal or distal hypoplastic aortic arch. In small children, particularly in the presence of hypoplastic aortic arch, our policy was to consider resection and endto-end anastomosis enlarged to the aortic arch (extended end-to-end) as the first-line technique of surgery.

Results. 1. Immediate results. There was no mortality in both groups. The comparisons of the study outcomes are presented in Table 2. The mean pre-operative pressure gradient in group 1 decreased from $59.3 \pm 18.7$ to $17.5 \pm 7.4$
Table 2

Comparison of the study outcomes between the study groups

\begin{tabular}{lccc} 
& $\begin{array}{c}\text { Group 1 } \\
\text { Balloon } \\
\text { angioplasty } \\
(\mathbf{n = 1 8 )}\end{array}$ & $\begin{array}{c}\text { Group 2 } \\
\text { Surgery } \\
(\mathbf{n = 4 1 )}\end{array}$ & p value \\
\hline Peak pressure gradient $(\mathrm{mmHg})$ & & \\
\hline $\begin{array}{l}\text { Immediately after } \\
\text { procedure }\end{array}$ & $17.5 \pm 7.4$ & $14.2 \pm 6.3$ & 0.17 \\
\hline After 6 months & $41.5 \pm 12.1$ & $15.6 \pm 6.4$ & $<0.05$ \\
\hline After 12 months & $48.3 \pm 16.5$ & $18.7 \pm 9.7$ & $<0.05$ \\
\hline Ejection fraction (\%) & $63 \pm 7.2$ & $67 \pm 8.6$ & 0.26 \\
\hline Hospital Stay (days) & $6.4 \pm 3.6$ & $21.5 \pm 8.7$ & $<0.05$ \\
\hline $\begin{array}{l}\text { Re-do Procedure due to } \\
\text { recoarctation (1st year) }\end{array}$ & $13(72.2 \%)$ & $1(2.4 \%)$ & $<0.05$ \\
\hline Mortality & 0 & 0 & -
\end{tabular}

$\mathrm{mmHg}$ post-operative $(\mathrm{p}<0.05)$. In group 2 , the mean pressure gradient was reduced from $57.4 \pm 16.5$ to $14.2 \pm 6.3$ $\mathrm{mmHg}(\mathrm{p}<0.05)$. The mean hospital stay was $6.4 \pm 3.6$ days in the balloon angioplasty group and $21.5 \pm 8.7$ days in the surgery group, which constitutes a significant statistical difference $(\mathrm{p}<0.05)$.

All complications that occurred within 30 days after intervention are shown in Table 3.

Artery-section was required to get access to the femoral artery in one patient following percutaneous intervention. No difference in the length of the legs was noted in subsequent follow-up. Two patients had chylothorax after surgical aortoplasty and prolonged chest drainage. All patients were treated conservatively. In the BA group, no patient required blood transfusion. In the surgical group, 2 patients had anemia requiring blood transfusion after surgery, 3 patients in the surgical group had lung atelectasis, 2 had chest wound infection. Overall, $22 \%$ of the surgical

Table 3

Complications within the 30 days after intervention

\begin{tabular}{lccc} 
Complications & $\begin{array}{c}\text { Group 1 } \\
\text { Balloon } \\
\text { angioplasty } \\
(\mathbf{n = 1 8 )}\end{array}$ & $\begin{array}{c}\text { Group 2 } \\
\text { Surgery } \\
(\mathbf{n = 4 1 )}\end{array}$ & p value \\
\hline Intimal tear & 1 & 0 & - \\
\hline Chylothorax & 0 & 2 & - \\
\hline Wound infection & 0 & 2 & - \\
\hline Aortic aneurysm & 0 & 0 & - \\
\hline Atelectasis & 1 & 3 & - \\
\hline Blood transfusion & 0 & 2 & - \\
\hline $\begin{array}{l}\text { Total } \\
\text { complications }\end{array}$ & 2 & 9 & $<0.05$
\end{tabular}


group patients had at least one complication after surgery, compared with $11 \%$ of the BA group patients $(<0.05)$.

2. Follow up. All patients accepted a median follow-up of 19 months (range, 8 to 48 months). Echocardiography was performed to measure the peak transcoarctation gradient every 6 to 12 months or when a weak femoral pulse was noticed at follow-up. Recoarctation was defined as a transcoarctation gradient $>25 \mathrm{mmHg}$ measured by transthoracic echocardiography and $>20 \mathrm{mmHg}$ obtained during a follow-up cardiac catheterization. The indications for reintervention included persistent large aortic arch gradient, weak femoral pulse, and hypertension.

No mortality was encountered in this series. In group 1 , recoarctation occurred in $13(72.2 \%)$ patients. All recoarctations were localised at the site of the former coarctation ridge and membranous. Neither isthmus nor arch hypoplasia was found. These children were under 3 months at primary treatment. All patients underwent surgical repair. In group 2, recoarctation occurred in $1(2.4 \%)$ patient. This recoarctation was found to be localised, limited to the site of the anastomosis. Hypoplasia of the aortic isthmus and/or arch was not encountered. Subsequently, BA was performed successfully in this patient. No aneurysm formation was encountered in this series.

Discussion. Surgical repair has provided adequate treatment for patients with this malformation since Crafoord described a successful repair of patients with CoA in 1946 [1, 2]. Balloon angioplasty has been proposed as a viable alternative to surgery in primary treatment of CoA in 1982 [1, 2]. In spite of disappointing results of BA in initial reports, subsequent experience appears favorable, although the necessity of long-term follow-up continues to exist. However, the number of studies comparing BA with surgical repair is limited.

Significant reduction of peak-to-peak systolic gradients can be accomplished with both surgery and BA, as shown in literature $[2,4,5]$. Early mortality rate was also similar, but BA revealed much higher rate of recoarctation in infants as compared with those who underwent surgical repair in reviewed literature [3-5].

Recoarctation as a late complication is found to occur in 10-30\% after surgery [2-6]. Varying occurrence of restenosis has also been encountered after BA, ranging from 11 to $60 \%$ [1, 2, 4, 5]. This variation may depend on specific aspects of surgical/angioplasty technique, including patch material, extension of resection and balloon diameter. The possible mechanisms in the process of recoarctation related to these different techniques consist of inadequate growth of the anastomosis, active fibrosis and narrowing at the anastomotic site, thrombosis at the suture line, and retention of abnormal, possibly ductal, tissue.In our study Re-do procedure after balloon angioplasty was performed with a greater incidence compared with the surgery group. The reintervention in BA group was performed at a mean $4.5 \pm 2.1$ of 2 to 12 months after initial intervention for CoA.

In our study, BA was associated with a high success rate, low complication rate, and short hospital stay. These results may suggest BA as a first-line therapeutic option in the management of discrete CoA in critically ill infants with congestive heart failure. Similar experiences were also reported by other investigators [4-6]. The present study showed that BA was as efficacious as surgery to provide immediate gradient relief following the procedure in a wide spectrum of patients diagnosed with CoA.

Conclusions. We conclude that both surgical repair and balloon angioplasty for native coarctation of the aorta in infants were effective and beneficial. These data suggest that balloon angioplasty can be acceptable alternative to surgical treatment but due to the high level of recoarctation this method may be considered in critically ill infants with congestive heart failure as a primary palliative procedure. The limitations of this study were its retrospective, nonrandomized nature, and smaller case numbers.

\section{References}

1. Balloon Angioplasty versus Surgical Repair of Coarctation of Aorta in Infants / Fariba Alaei, MD, Mohammad Yousef Arabi Moghadam, MD, Hojat Mortaezaian, MD et al. // J Teh Univ Heart Ctr. - 2011. - Vol. 6 (3). - P. 134-137.

2. Comparison of surgical repair with balloon angioplasty for native coarctation in patients from 3 months to 16 years of age / Ronald J. Walhouta, Jaco C. Lekkerkerkera, Gordon H. Oron et al. // European Journal of Cardio-thoracic Surgery. - 2004. - Vol. 25. - P. 722-727.

3. Balloon Angioplasty of Native Coarctation and Comparison of Patients Younger and Older Than 3 Months / ChengLiang Lee, MD, PhD; Jeng-Feng Lin, MD; Kai-Sheng Hsieh, MD et al. // Circ J. - 2007. - Vol. 71. - P. 17811784.

4. Comparison Between Balloon Angioplasty and Surgery for Native Coarctation of the Aorta in Neonates and Young Infants / Shan-Miao Lin, Haw-Kwei Hwang, Shye-Jao Wu and Ming-Ren Chen // Interventional Cardiology. Acta Cardiol Sin. - 2008. - Vol. 24. - P. 204-8.

5. Long-Term Outcomes of Native Coarctation of the Aorta after Balloon Angioplasty or Surgical Aortoplasty in Newborns and Young Infants Less Than 3 Months of Age / Hsin-Hui Chiu, Jou-Kou Wang, Yih-Shang Chen et al. |// Acta Cardiol Sin. - 2013. - Vol. 29. - P. 168-174.

6. Hussam Suradi, Ziyad M. Hijazi. Current management of coarctation of the aorta // Global Cardiology Science and Practice. - 2015. - Vol. 44. 


\title{
Порівняння результатів балонної ангіопластики та хірургічного лікування коарктації аорти у немовлят
}

\author{
Труба Я. П., Дзюрий І. В., Дяченко В. Л., Плиска О.І., Іманов Є., Лазоришинець В. В. \\ ДУ «Національний інститут серцево-судинної хірургії імені М. М. Амосова НАМН» (Київ)
}

Коарктація аорти (CоA) - це дискретний стеноз проксимального відділу грудної аорти. Методи лікування в даній віковій групі включають балонну ангіопластику та хірургічну корекцію. Балонна ангіопластика - малоінвазивний спосіб корекції дискретної коарктації, але цей метод залишається суперечливим як стратегія первинної терапії.

Мета дослідження - порівняння ефективності та результатів балонної ангіопластики та хірургічного корекції коарктації аорти у немовлят.

Матеріал і методи. У період із січня 2011 по грудень 2017 року в ДУ «Національний інститут серцево-судинної хірургії імені М. М. Амосова НАМН» обстежено 59 пацієнтів із коарктацією аорти. Пацієнти були розділені на дві групи: перша група - 18 пацієнтів, яким виконали балонну дилатацію коарктації аорти; друга група - 41 пацієнт, яким виконали хірургічну корекцію. Пацієнти зі складними супутніми внутрішньосерцевими аномаліями серця до цього дослідження не були включені.

Результати. Безпосередні результати не виявили суттєвої різниці в ефективності двох методів $(\mathrm{p}=0,06) . \mathrm{У}$ той самий час відсоток рекоарктації був значно нижчим у групі хірургічного лікування $[1(2,4 \%)$ проти 13 (72,2\%), $\mathrm{p}=0,0017]$. Середній термін перебування в лікарні статистично відрізнявся і становив $6,4 \pm 3,6$ дні в групі ангіопластики та $21,5 \pm 8,7$ дні в групі хірургічного лікування $(\mathrm{p}<0,05)$. Аневризм у місці корекції не було в обох групах.

Висновки. Як хірургічна корекція, так і балонна ангіопластика коарктації аорти у немовлят була ефективною та мала добрий безпосередній результат. Проведене дослідження вказує на те, що балонна ангіопластика може бути прийнятною альтернативою хірургічному лікуванню, однак через високий рівень рекоарктації цей метод може бути використаний у хворих із критичною коарктацією аорти, ознаками вираженої серцевої недостатності та низькою фракцією викиду лівого шлуночка як паліативна процедура.

Ключові слова: коарктація аорти, балонна ангіопластика, немовлята.

\section{Сравнение результатов баллонной ангиопластики и хирургического лечения коарктации аорты у младенцев}

\author{
Труба Я. П., Дзюрий И. В., Дьяченко В. Л., Плиска А.И., Иманов Е., Лазоришинец В. В. \\ ГУ «Национальный институт сердечно-сосудистой хирургии имени Н. М. Амосова НАМН» (Киев)
}

Коарктация аорты (CoA) - это дискретный стеноз проксимального отдела грудной аорты. Методы лечения в данной возрастной группе включают баллонную ангиопластику и хирургическую коррекцию. Баллонная ангиопластика - малоинвазивный способ коррекции дискретной коарктации, но этот метод остается противоречивым как стратегия первичной терапии.

Цель исследования - сравнение эффективности и результатов баллонной ангиопластики и хирургической коррекции коарктации аорты у младенцев.

Материалы и методы. В период с января 2011 по декабрь 2017 года в ГУ «Национальный институт сердечнососудистой хирургии имени Н. М. Амосова НАМН» обследовано 59 пациентов с коарктацией аорты. Пациенты были разделены на две группы: первая группа - 18 пациентов, которым выполнили баллонную дилатацию коарктации аорты; вторая группа - 41 пациент, которым выполнили хирургическую коррекцию. Пациенты со сложными сопутствующими внутрисердечными аномалиями сердца в это исследование включены не были.

Результаты. Непосредственные результаты не выявили существенной разницы в эффективности двух методов $(\mathrm{p}=0,06)$. В то же время процент рекоарктации был значительно ниже в группе хирургического лечения [1 $(2,4 \%)$ против 13 (72,2\%), p=0,0017]. Средний срок пребывания в госпитале статистически отличался и составил 6,4 $\pm 3,6$ дня в группе ангиопластики и $21,5 \pm 8,7$ дня в группе хирургического лечения $(\mathrm{p}<0,05)$. Аневризм в месте коррекции не было в обеих группах.

Выводы. Как хирургическая коррекция, так и баллонная ангиопластика коарктации аорты у младенцев была эффективной и имела хороший непосредственный результат. Проведенное исследование указывает на то, что баллонная ангиопластика может быть приемлемой альтернативой хирургическому лечению, однако из-за высокого уровня рекоарктации этот метод может быть использован у больных с критической коарктацией аорты, признаками выраженной сердечной недостаточности и низкой фракцией выброса левого желудочка как паллиативная процедура.

Ключевые слова: коарктация аорты, баллонная ангиопластика, младенцы. 